\title{
Cognitive Mapping of Geotechnical Practices as Cost Overrun Drivers in Highway Projects
}

\author{
Alolote Amadi ${ }^{1 *}$ and Anthony Higham ${ }^{2}$
}

\begin{abstract}
Cost overruns experienced in transportation infrastructure projects continues to remain an issue of wide scholarly interest throughout the developed and developing world. Adopting a geotechnical trajectory, this research investigates the cause of unusually high cost overruns experienced in highway projects, executed in the tropical wetland setting of the Niger Delta region of Nigeria. Using the case study research strategy, archival data is sourced along with sixteen interviews conducted within the three highway agencies responsible for infrastructure project delivery in the region. The qualitative data gathered was comprehensively analysed using deductive-inductive thematic analysis. The results of the analysis identified latent triggers such as non-adherence to geotechnical best practices, amidst a wide array of unanticipated social constructs, which festered in the practises of the highway agencies. The interplay of the emergent social constructs with the fundamental geotechnical triggers is cognitively mapped out, relaying the intricate web of the contextual dynamics, driving the unusually high level of cost overruns experienced in highway project delivery in the Niger Delta. The study submits that the phenomenon of cost overruns in highway projects is multi-hydra headed, driven by a complexity of technical and social variables, contextually specific to the practices of highway organisations.
\end{abstract}

\section{Keywords}

Cognitive Mapping, Highway Organisations: Project Delivery; Cost Overruns

\footnotetext{
${ }^{1}$ School of the Built Environment, University of Salford, Salford, UK amadialolote@yahoo.com (corresponding author)

${ }^{2}$ School of the Built Environment, University of Salford, Salford, UK a.p.hiham@salford.ac.uk
} 


\section{Introduction}

The problem of significantly high investments on road construction in the Niger Delta, has become a subject of grave concern to government. Sunjka and Jacob (2013) reported that presently, budgetary allocation for roads in the region ranges between $60-70 \%$ of annual capital expenditure on infrastructure. Yet, extensive areas of the Niger Delta basin are not traversed by roads, due to construction difficulties and complimentary costs associated with road construction in the region, mostly attributed to the prevalence of expansive clayey sub-soils (Oguara, 2002: Central Bank of Nigeria, 2003; Fatokun and Bolarinwa, 2011).

However, despite the environmental handicaps of the region, in recent times there has been a renewed drive to open up and link remote areas of the Niger Delta to foster their economic development (NDDC, 2013). Consequently, a multiplicity of roads is being constructed concurrently across the Niger Delta by the various highway agencies in the region. The local literature, however, indicates that it is not the initiation of road projects that is the problem, the fundamental problem being their completion, with funding shortfalls responsible for the vast majority of delayed or abandoned projects (Ayodele and Alabi, 2011; Ihuah and Benibo, 2014). For local communities, these uncompleted road projects constitute a hindrance to vehicular and human traffic, as well as impact negatively on economic activities. As physical evidence captured in Figure 1 shows, following abandonment, these partially complete projects are not securely protected until additional funds can be approved. Rather the partially constructed highway is unofficially handed over to the local community. As a result, the incomplete structure degenerates, often to such an extent that the highway, designed to help the local community, becomes a death trap (Momoh et al., 2008; Emujakporue, 2012).

The aftermath of these issues, is evident in the warfront like landscape of the Niger Delta region, following repeated bombings and explosion of government assets by communities, which has been reported by the local and international media (BBC, 2016). The data, presented in Table 1a and $\mathrm{b}$ as evident from the scholarly literature, illustrates the failure of highway agencies, such as the NDDC, to deliver the needed infrastructure projects. For instance, the data in Table 1 provided from Okon (2009) analysis evidences that only $26 \%$ of commissioned road projects actually achieved completion between 2001 and 2008. With more recent data from 2001 to 2014 (Table 2), pooled from Isidiho and Sabran (2015) and Amadi (2016), further reinforcing the dismal completion rate for infrastructure projects in the Niger Delta.

Despite the abysmal completion rates for road construction projects in the Niger Delta region, as Falade (2016) discovered, completion does not always indicate success, with most, if not all, completed highway projects recording astronomically high cost overrun figures: Amadi (2016) revealed extreme cost overruns as high as $1900 \%$ based on a sample of 61 completed highway projects awarded from 2002, particularly for projects traversing the swamps. Mean cost overrun value for the projects was $216.47 \%$ over

Figure 1. Degenerating Uncompleted and Abandoned Road Projects in the Niger Delta

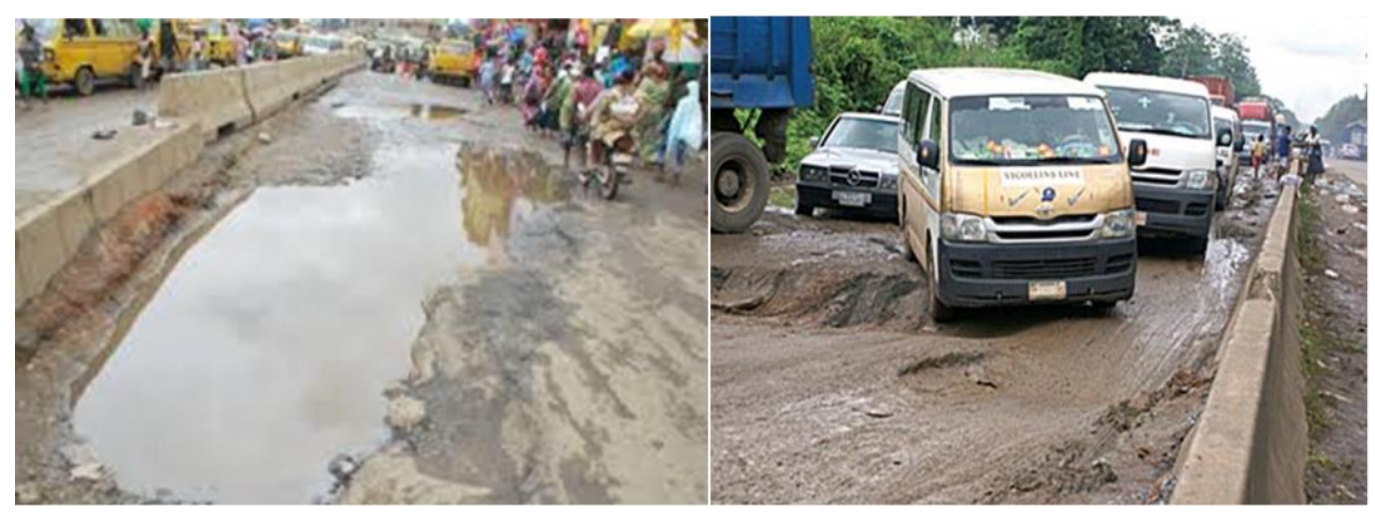

The Engineering Project Organization Journal (C)2017 Engineering Project Organization Society www.epossociety.org 
Table 1. Infrastructure Projects Completion Status in the Niger Delta (2001 -2008)

\begin{tabular}{|l||l|l||l||}
\hline Infrastructure Type & No. Initiated & Completed & \% Completed \\
\hline \hline Roads & $156(3,000 \mathrm{Km})$ & $780 \mathrm{Km}$ & 26 \\
& & & \\
\hline \hline Bridges & 47 & - & 0 \\
\hline \hline Water Supply & 283 & 78 & 28 \\
\hline \hline Electrification & 316 & 137 & 42 \\
\hline
\end{tabular}

(Source: Okon, 2009)

initial budget estimates. Whilst Okon (2009) quoted cost overrun figures as high as $500 \%$ associated with some of the completed highway projects in the Niger Delta region. The levels of cost overruns experienced in highway project delivery in the Niger Delta, is thus remarkably high compared to those evident for highway projects reported in the literature. Typically, Flyvbjerg et al. (2002) revealed from a sample of 258 infrastructure projects sampled worldwide, cost overruns, were on average $20 \%$ for road projects. Whilst Odeck (2004) analysed cost overruns for road construction projects in Norway, revealing an average of $7.9 \%$.

Several empirical studies have attributed the extreme cost escalations to the various geologic environments in the Niger Delta region, which bears significantly high risks. Vulnerability to ravaging environmental (flood and erosion) related disaster; adverse weather conditions; inaccessible and geo-hazardous impassable wetland terrain, were some of the distinct attributes of the region, cited as responsible for the current state of highway project delivery (Joseph, 2012; Ihuah and Benibo, 2014).
However, several other empirical studies in the local literature (Mansfield et al., 1994; Okpala and Aniekwu, 1998; Ajibade and Odeyinka, 2006), have consistently listed lack of best practices, such as: weak and insufficient technical studies and preliminary engineering, design and specification deficiencies as well as inaccurate budgetary and engineering design estimates as contributing to the high spate of project delays and abandonment in Nigeria.

As a result of the extensive local literature supporting the link between geology, the lack of geotechnical best practices, and cost and time overruns, it can be argued that in the context of the Niger Delta, the prevalence of the outlined issues in practice, would culminate in a huge disparity between initial budgeted estimates, design estimates, and tender estimates in relation to final cost. This is further situated against the backdrop of the widely publicised cases and statistics offered by the technical press across the developed and developing world on issues of inadequate preliminary geotechnical engineering in public projects, and the resultant financial post contract issues that have hunted these projects. Typically,

Table 2. Infrastructure Projects Completion Status in the Niger Delta (2001 -2014)

\begin{tabular}{|l||l||l||}
\hline \hline Project Type & No of Projects & No/\% Completed \\
\hline \hline Roads & 207 & $75(36 \%)$ \\
\hline Bridges & 81 & $6(29 \%)$ \\
\hline \hline Water Supply & 462 & $211(46 \%)$ \\
\hline \hline Electrification & 512 & $263(51 \%)$ \\
\hline \hline Flood Control & 31 & $14(45 \%)$ \\
\hline \hline Canalisation & 27 & $9(33 \%)$ \\
\hline
\end{tabular}

(Source: Isidiho and Sabran, 2015; Amadi, 2016) 
notoriously cited highway projects which experienced cost overruns of huge proportions, such as: The Big Dig, a central artery project in Boston; The M60 Manchester ring road, and the Hallandsås tunnel project in Sweden, were all underlain by geotechnical themes (Creedy et al., 2010). Discussion of geotechnical issues are also dominant in the vast array of scholarly engineering literature offering explanations for the high levels of cost overruns experienced in highway projects, yet no form of in-depth qualitative narrative has been used to explain its impact on cost overruns (Ashton, and Gidado, 2002. Creedy et al., 2010). Against this backdrop, the paper aims to qualitatively investigate, and cognitively map out the loopholes in the geotechnical practices of highway organizations as potential triggers to cost overruns in highway projects.

\section{Theoretical Framework}

Several contemporary works have advanced theories explaining cost overruns in public projects. Most of these theories are however relate specifically to the context of highway projects executed in developed countries. These include: Flyvbjerg et al.'s (2002) Theory of Strategic Misrepresentation; Theory of Lock-in by Cantarelli et al. (2010); Relay Race theory of leadership and Governance by Gil and Lundrigan (2012); Latent Pathogens theory by Love et al. (2012), Metaorganizational theories of Core and Periphery developed by Lundrigan and Gill (2013) as well as Johansen (2015) Uncertainty theory. Flyvbjerg et al. (2002), emphasized the systematic nature of deliberate cost underestimation in getting funding approval for public projects, led to cost overruns. Cantarelli et al. (2010:793) developed a framework explaining how Lock-in, 'associated with the inability to withdraw from obligations made in the decision-making process', sets the pace for path dependency, irrespective of the availability of optimal alternatives, resulting in cost overruns. Love et al. (2012) systematically analyzed how 'Latent Pathogens (errors)', in organizations can be unintentionally triggered and culminate in cost overruns. Pathogens according to Love et al. (2012:3) represent "the latent conditions that lay dormant within a system until an error comes to light". Such pathogens may thus be considered the norm but significantly deviate from best practice. Johansen (2015) as well as Gil and Lundrigan (2012; 2013) conceptualised the multiplicity of risk and uncertainty inherent in projects amidst various stakeholders' expectations and the associated managerial difficulties, as a fundamental characteristic of public projects that trigger cost overruns.

Whilst these qualitative narratives offered in the literature make a substantial contribution to the literature on cost overrun explanations, a limitation is set on them, based on the external validity of such studies to highway projects executed in developing nations. As such an easily identifiable loophole in the generalisability of the conclusions reached by these studies, in the context of this research, is that they are based on studies of projects executed within the context of developed countries. Typically, Flyvbjerg et al.'s (2002) conclusions were drawn based on sample data for highway projects mainly in developed nations, located in the Northern Hemisphere, with the majority of the projects selected from Europe and North America with little focus on developing nations such as those on the African continent. Cantarelli et al. (2010) theory was contextualized for projects in the Netherlands, while Gil and Lundrigan $(2012 ; 2013)$ theories were drawn from the longitudinal study of three mega projects in the UK. This limits their generalisability to the distinctive settings of highway development in developing countries, a fundamental argument further posed by the study: That the contextual settings of highway project delivery in the developed and developing world, are different.

Unlike the preceding studies analyzed, Morris (1990) argued that a "vicious cycle of delays and short-funding" triggered due to poor project planning by overly bureaucratic government agencies, amidst low levels of technical capacity, mostly explained cost overruns in the developing world. It was noted that for public sector projects in India, cost and time overruns were unusually very high. The author provided empirical evidence which showed that most projects lacked adequate technical preparation at the front-end and where often fraught with technical difficulties. It was revealed that funds, adequate for the full and timely completion of three to four projects, were spread- 
out too thinly to accommodate up to six to seven projects. Projects to be completed where then prioritized, with others carried forward to subsequent budgets.

Despite a comprehensive literature search, Morris (1990), is the only study identified in the literature, which offers a qualitative narrative specifically contextualized in a developing country, albeit specific to Indian projects. This is relative to the nomenclature of the empirical literature on cost overruns in developing nations, which predominantly lean towards the use of survey research (Kaming et al., 1997; Chang 2002; Aibinu and Odeyinka, 2006; Lo et al., 2006; Kaliba, et al., 2008; Memon et al., 2011; Ubani, 2015). The sparsity of in-depth theoretical narratives explaining the systematic build-up of cost overruns in the developing world, is thus a further discernible gap in the literature. Considering the strong consensus of opinions, identifying the potential limitations in Nigerian engineering practice, and in view of the peculiarity of the Niger Delta terrain, as well as the series of project delays and abandonments due to funding shortfalls, historically chronicled in the literature, the study is of the view that Morris' (1990) assertion that a "vicious cycle of delays and short-funding" in public projects are significant to explaining cost overruns in the Niger Delta. This is adopted alongside Love et al.'s (2012) latent pathogen theory, the underlying logic being that whilst other qualitative narratives from the developed world mostly focus in explaining the inherent biases associated with the leadership, governance and management of public projects, Love et al. (2012) similar to (Morris 1990) conceptualise cost overruns as being the outcome of practice-based technical lapses. It is thus the study view point that the evident gaps identified in the literature warrants greater exploration of how geotechnical pathogens which may lay dormant within the linear process configuration of projects delivered by highway organizations, can be triggered, culminating in significant cost overruns during the post-contract phase, as the project team deal with the cycle of delay and funding requirement. Geotechnically induced pathogens, as plausible explanations for cost overruns are thus specifically investigated using cognitive mapping as a methodology necessary to provide an in-depth theoretical narrative explaining the systematic build-up of cost overruns in Niger Delta's highway projects.

However, in adopting this theoretical trajectory, the study does not seek to downplay or dispute the presence of other factors that trigger cost overruns in the developing world. Therefore, although other triggers to cost overruns are acknowledged as present in highway projects, the study primarily sets off to investigate geotechnical factors, that explain the progressive build-up of cost overruns in project phases.

\section{Suspected Geotechnical Pathogens in the Practices of Niger Delta's Highway Agencies}

Various mediums of ensuring adequate geotechnical risk containment have deduced as best practices, for clients of highway projects at the precontract phases, necessary to avert cost overruns. Based on the dictates of geotechnical best practice advocated in the literature, several potential costoverrun drivers have been identified by the study, and are suspected as the technical lapses in the practises of Niger Delta's highway agencies driving the phenomena of unusually high cost overruns (Table 3 ).

The study thus investigates lack of adherence to geotechnical best practices, as a logical theoretical perspective, necessary to understand cost overruns experienced in the delivery of highway projects in the Niger Delta. Verification of these suspected gaps in knowledge, as summarised in Table 3, which principally revolve around management of geotechnical risks inherent in the wetland setting of the Niger Delta, constitute the rationale of the study. Scrutinising the practises of the highway agencies, therefore constituted the first step, towards understanding the propagation of unusually high cost overruns in the Niger Delta's highway project delivery. 
Table 3. Identified Cost Drivers/Potentials for Added Value in Highway Investment

\begin{tabular}{|c|c|}
\hline Project Phase & "Suspected Gaps in Knowledge \\
\hline "Conceptual Phase & $\begin{array}{l}\text { Use of non-differentiated/uniform cost per kilometre of road length } \\
\text { estimate that is not reflective of the typically heterogeneous ground } \\
\text { profile. As opposed to using more deterministic bespoke estimates in } \\
\text { budget preparation (AACE, 1997; Reiley et al., 2004; Romero and Stolz, } \\
2009 \text { ) }\end{array}$ \\
\hline Design Phase & $\begin{array}{l}\text { Adequacy of ground investigations desk studies; preliminary } \\
\text { reconnaissance; and detailed explorations, as necessary precursors to } \\
\text { preparing highway designs and computing detailed estimates (ICE, 1999; } \\
\text { Clayton 2001; Ashton, and Gidado, 2002). }\end{array}$ \\
\hline $\begin{array}{l}\text { Tendering and } \\
\text { Contracting Phase }\end{array}$ & $\begin{array}{l}\text { Non-inclusion of GIR and DSC clauses in contract documentation; } \\
\text { - Whether a ground investigation report is included as part of the } \\
\text { contract documentation, and where provided, is if truly } \\
\text { representative of the physical conditions of site; } \\
\text { in the event of encountering a subsurface condition different from } \\
\text { that which was indicated in the contract, are provisions made via } \\
\text { DSC clauses, to provide financial compensation, and therefore } \\
\text { avoid costly disputes (Moleenar et al., 2006; Chan and Au, 2007; } \\
\text { Wong, 2012). } \\
\text { Inadequate geotechnical criteria in contractor selection: } \\
\text { Specific geotechnical qualifications for key personnel; } \\
\text { geotechnical project experience; references from past projects } \\
\text { with specific geotechnical issues; and proof oflocal geotechnical } \\
\text { project experience. } \\
\text { Evaluation of contractors' technical proposal; } \\
\text { Deployment of a defined algorithm: A function of } \\
\text { technical/financial evaluation (Crowley and Hancher, 1995; } \\
\text { Gransberg and Gad, 2014). }\end{array}$ \\
\hline
\end{tabular}

GIR: Ground Investigation Reports DSC: Differing Site Condition

\section{Method of Study}

The research was conducted as a single case study of 'cost overruns in Niger Delta's highway projects', through the lenses of a critical realist philosophical perspective. Critical realism per Huberman and Miles (1994) calls for both deductive and inductive reasoning to establish causal connections in credible ways, by providing descriptive accounts as evidence to back up the plausibility of such explanation. The unit of analysis, towards which all data collection effort was targeted, was 'the geotechnical practises highway agencies in the geologic setting of the Niger Delta'.

Qualitative data was gathered via 16 semistructured interviews supplemented by documentary/archival analysis of 61 completed projects executed by the three highway agencies in the region. Ten interviews were conducted with technical professionals within the three highway agencies. To recruit participants from the highway organisations for the interviews, introductory information explaining the nature and purpose of the research was sent to the respective highway organisations. The respondents who served as key informants, were chosen in relation to their technical job description (Civil Engineers and 
Table 4. Interview Respondents

\begin{tabular}{llll}
\hline & \multicolumn{3}{c}{ Years of Experience } \\
\cline { 2 - 4 } Job Description & $0-10$ & $10-15$ & $16-25$ \\
Civil Engineers & 1 & 2 & 1 \\
Quantity Surveyors & 3 & 2 & 1 \\
\hline
\end{tabular}

Quantity Surveyors) within the highway agencies. As they were relied on as the primary source of information on the geotechnical practices at the design and cost estimation phases of their organisations, it was necessary to eliminate influences, due to their hierarchical ranking, to minimise bias in the information gained. Ten semistructured interviews were thus carried out with the managerial staff, as well as operational personnel. Table 4 shows the respondent demographics in terms of years of experience professional job description of the interview respondents.

This was supplemented by different interview sets with three contractors and three consultants external to, but registered with the highway agencies (one from each), to build in and control for their perspectives. The level of experience and academic qualifications, necessary to provide the required technical information sought, was used to adjudge the consultants' adequacy, whilst the volume of road contracts executed by the contractors, established their relationship with the highway agencies.

The interview questions touched upon themes of the geotechnical inputs in preliminary planning, budgetary, design and contracting, with different lines of questioning designed for the different sets of respondents, to accommodate for differences in respondents' professional roles and academic backgrounds. As such four sets of interview questions structured in non-revealing patterns were used to elicit information relevant to confirming the suspected gaps in knowledge. This measure further strengthened the reliability of data obtained on each highway organization, achieved by a cross comparison of information provided by the different cadre of respondents. Multiple informants from each highway organization were thus used to elicit relevant information, as opposed to using one key informant, selected to speak on behalf of the highway organization. The interviewee selection method deployed for the study is thus an adaptation of 'Key Informant Research' which is common with organizational research, used to retrieve factual data rather than attitudinal data (Bryman, 1989). The rationale for adopting this approach is based on findings from a number of older organizational studies in the literature (Philips 1981; Bryman, 1989) that have pointed out the limitations of using a single informant. Typically, several issues were raised, such as:

- Whether it is possible for a single informant to provide accurate information on the organization as a whole.

- The possibility of variability of status of the informant affecting the reliability of information provided, which may have implications for the comparability of data.

- The potential for error, ignorance bias or deliberate distortion of facts from a single informant.

It is however recognized that although aggregated accounts from the multiple participants may not completely eliminate these potential shortcomings, it greatly minimizes them. Furthermore, depending on the on the respondent or the specific organisation, certain questions were asked which were omitted in others. Additional questions not originally part of the interview protocol was also introduced to probe unanticipated issues that occurred during the interview, and which were considered crucial to the study. This discretionary method of interviewing was thus tailored to suit the prevailing context of the individual interviews. The interviews lasted approximately 45 minutes to one hour each, were conducted face-to face, tape recorded and transcribed verbatim. In addition to the audio recordings, the interviewer took notes on reflections to supplement the interview data that were obtained.

All necessary measures, relevant to improve and ascertain the reliability and accuracy of qualitative data collected, as posited by Yin (2014), were also ensured in this case study research, to establish the credibility of the study's contribution (in Table 5). 
Table 5. Measures of Validity and Reliability in this Case Study

\begin{tabular}{|c|c|}
\hline Measures & As applied to this Research \\
\hline $\begin{array}{l}\text { Construct } \\
\text { validity }\end{array}$ & $\begin{array}{l}\text { - Definition of concept, case and context being studied; } \\
\text { - Identifying units of analysis and acquiring data to measure them. } \\
\text { - Use is made of multiple sources of evidence from interviews, } \\
\text { documents and archives; } \\
\text { - Use of multiple key informants with multi-disciplinary perspectives; } \\
\text { the chain of evidence is increasingly established from the data, from } \\
\text { qualitative analysis of interview data; }\end{array}$ \\
\hline Internal validity & $\begin{array}{l}\text { - Pattern matching via thematic analysis of qualitative data; } \\
\text { - Ase of cognitive mapping to visually converge all sources of evidence; } \\
\text { - Addressing key rival and complementary explanations to cost } \\
\text { overruns. }\end{array}$ \\
\hline External validity & $\begin{array}{l}\text { - Use of theoretical framework derived from the literature as proposition } \\
\text { in the singular distinctive case study of the Niger Delta region }\end{array}$ \\
\hline Reliability & $\begin{array}{l}\text { - Preparation of pre-designed interview templates, ethical consent and } \\
\text { - Detroduction letters as part of case study protocol } \\
\text { - Detailed outline of data collection methods }\end{array}$ \\
\hline
\end{tabular}

\section{Data Analysis}

Template analysis was deployed to analyse the collated data. According to King (2004:21) when using template analysis:

"... the researcher produces a list of codes ('template') representing themes which will usually be defined a priori, but are modified and added to as the researcher reads and interprets the texts. The template is organized in a way which represents the relationships between themes, as defined by the researcher".

The appropriateness of this qualitative methodology is justified on the basis of the geotechnical issues pre-conceived, as the fundamental drivers of cost overruns in the Niger Delta region, due to its peculiar geologic setting. Reflexivity afforded by the use of this methodology further enabled the study to capture the richness of the data in the descriptions of additional codes. Inductive analysis was thus carried out as the second phase of the analysis, following the deductive phase, in the bid to gain knowledge based on previously un-anticipated themes and trends which emerged from the interview data. The interview transcripts were thus re-read and patterns repeated occurring across the data, matched. The analysis in this regard was thus carried out without a prior literature base, similar to grounded theorising. Using this analytical approach, a multiplicity of social constructs was inductively inferred as the barriers to geotechnical best practice, and by extension underlying contextual drivers to cost overruns.

The data analysis was carried out using the NVIVO-10 qualitative data analysis software, following the outlined logical steps (Table 6) inspired by King (2004). 
Table 6. Qualitative Analytic Procedure

\begin{tabular}{|c|c|c|c|}
\hline & $\begin{array}{l}\text { Qualitative } \\
\text { Analysis }\end{array}$ & Stages & Description \\
\hline 1. & \multirow{4}{*}{ 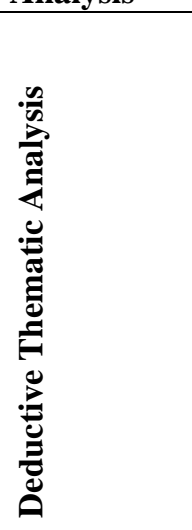 } & Development of Template & $\begin{array}{l}\text { Projection of conceptual mind map in } \\
\text { relation to logical flow of geotechnical } \\
\text { themes derived from the literature; }\end{array}$ \\
\hline 2. & & Initial Read through & Air brush reading of the interview notes; \\
\hline 3. & & Deductive A priori Coding & $\begin{array}{l}\text { Sorting and categorising interview } \\
\text { responses into apriori geotechnical } \\
\text { themes }\end{array}$ \\
\hline 4. & & Deductive Axial Coding & $\begin{array}{l}\text { Discovering subthemes and patterns } \\
\text { around the parent geotechnical themes }\end{array}$ \\
\hline 5. & \multirow{4}{*}{ 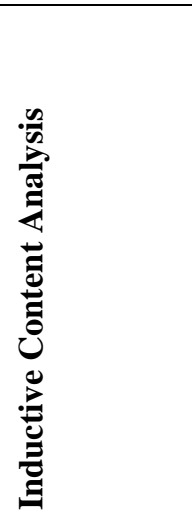 } & $\begin{array}{l}\text { Second Read Through (Bottom-up } \\
\text { reading) }\end{array}$ & $\begin{array}{l}\text { Reading the interview notes afresh from } \\
\text { a new perspective }\end{array}$ \\
\hline 6. & & Inductive Micro Coding & $\begin{array}{l}\text { Induce further micro themes related to } \\
\text { and impacting on geotechnical themes }\end{array}$ \\
\hline 7. & & Inductive Cluster analysis & $\begin{array}{l}\text { Cluster analysis of induced micro } \\
\text { themes into subthemes and emergent } \\
\text { parent themes; }\end{array}$ \\
\hline 8. & & Content analysis & $\begin{array}{l}\text { Further content analysis of induced } \\
\text { themes; }\end{array}$ \\
\hline 9. & & Cognitive mapping & $\begin{array}{l}\text { Conceptualisation of Cognitive map of } \\
\text { interrelated geotechnical and emergent } \\
\text { cost overrun drivers. }\end{array}$ \\
\hline
\end{tabular}


Figure 2. Conceptualization of Apriori Themes highlighting the flow of Geotechnical Input (GI)

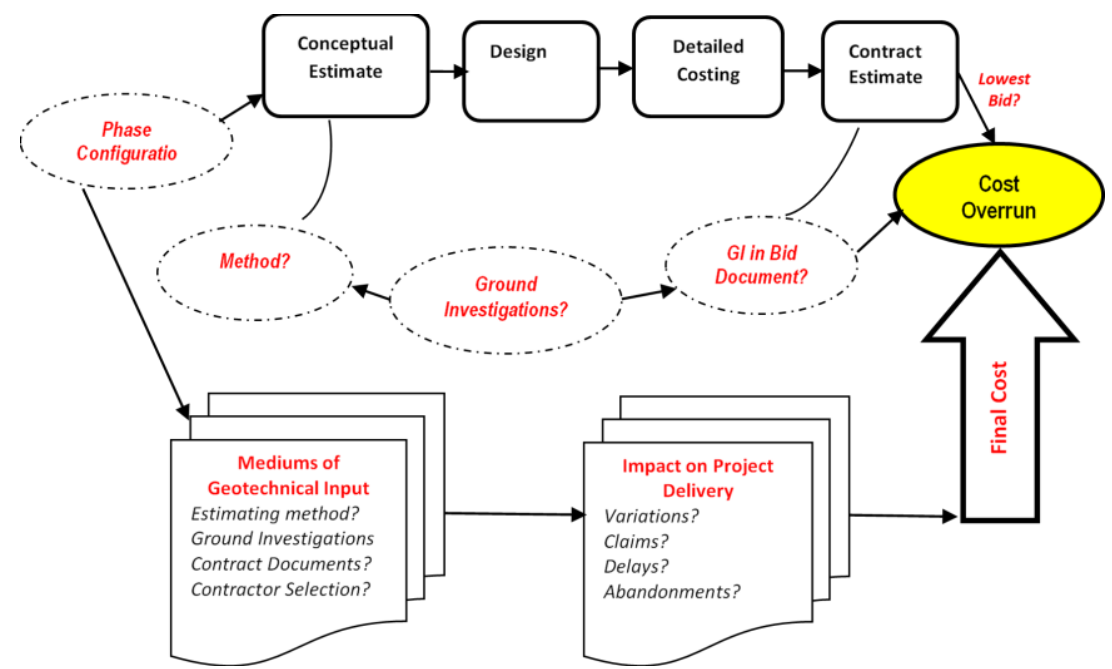

\section{Development of Template}

The drafting of the interview template was carried out with the objective of ascertaining the suspected gaps in knowledge, presupposed as the existing cost overrun drivers in the practices of highway agencies. Figure 2 shows the study's initial preconceived mind map generated from the literature, which served to define logical flow of geotechnical themes in the thematic analysis of the interview notes.

This progressive linear phase configuration, served as the blueprint, around which further emergent interwoven themes, induced as impacting on the level of geotechnical input were inferred. The resulting cognitive map of cost-overrun drivers is thus structured following this core conceptual projection.

\section{Deductive Axial Coding}

During the course of the coding, further sub-themes were derived from the parent geotechnical themes. The induced subthemes were noted in the institutional practices of all three highway agencies, which are primarily linked to the previously deduced themes.

\section{Second Read Through}

In line of the necessity of thinking outside the confines of the initially predetermined themes, requisite to maintain a measure of analytic distance, the interview data was re-read from a fresh perspective, to further induce themes which were displaying a discernible pattern across the data. A wide range of issues interlinking with the initial themes were noted as possible drivers to cost overruns, as they were consistently represented across most of the data.

\section{Inductive Air Brush Micro Coding}

At this phase of coding a long listing of about 89 themes and subthemes had been derived, including the fundamentally core geotechnical themes.

The additional themes, although linked to other themes, were not previously deduced through the synthesis of the literature, but were noted as repeatedly emphasized in the responses, and therefore inferred and included. This is captured in the snapshot of the NVivo 10 coding, shown in Figure 3 . The creation of new nodes to account for these emergent themes, during the coding was informed by the perception of their over-arching interface with, and impacts of differing magnitude on, the agencies' levels of geotechnical input in the phases of development, and by implication their complicity in determining the resultant level of cost overrun. 
The Engineering Project Organization Journal (January 2018) Volume 8

Figure 3. Snapshot of NVivo Coding

Nodes

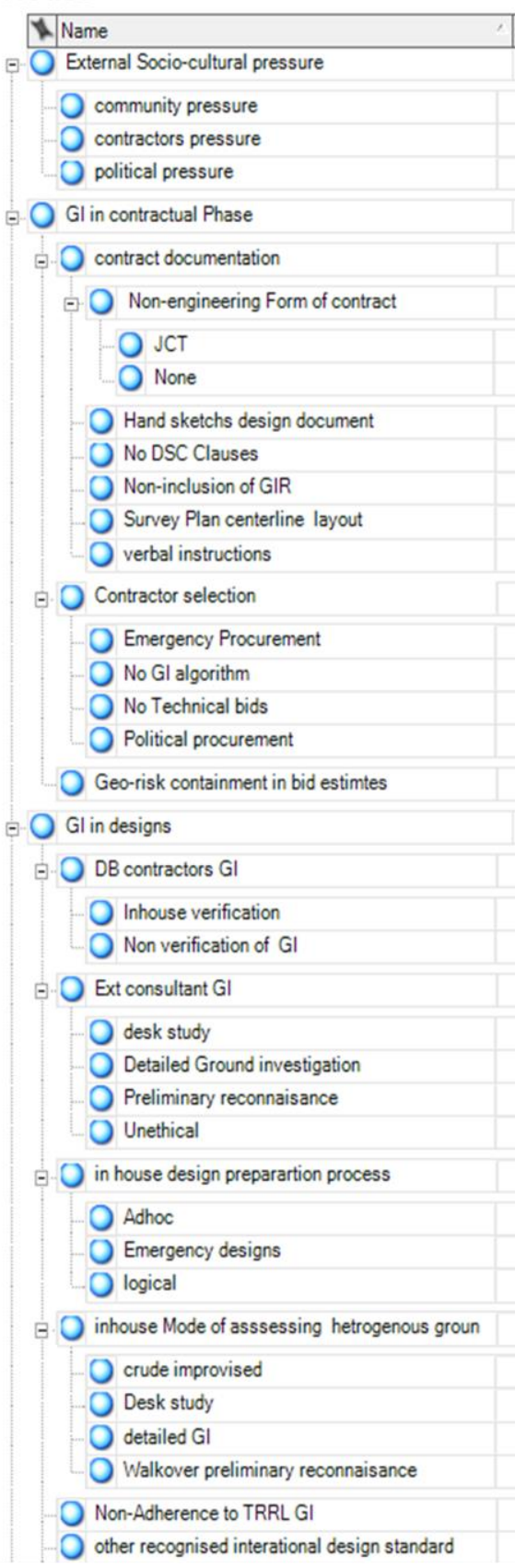

\section{Nodes}

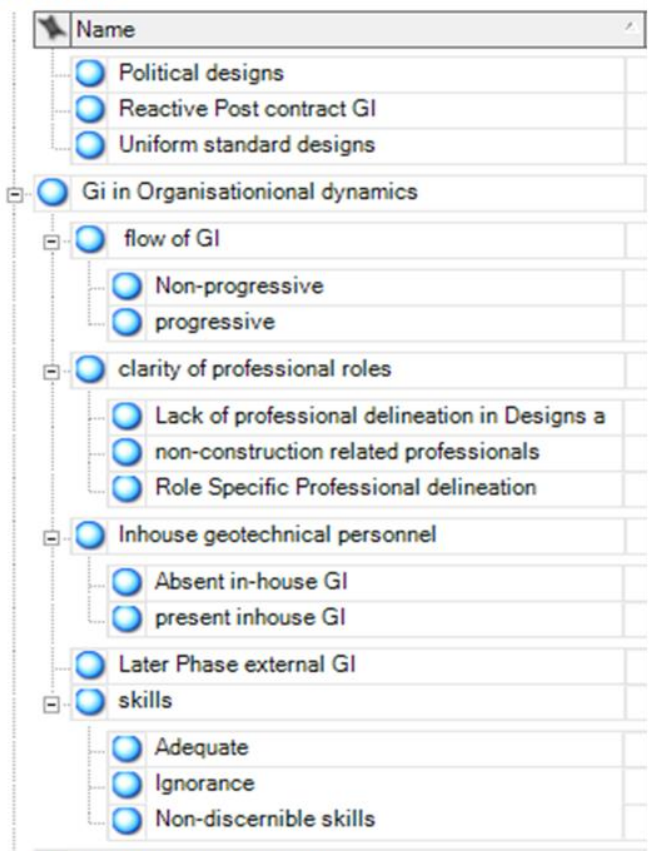

- $\mathrm{O}$ Gl relative to Project size

$$
\text { Community }
$$$$
\text { Major }
$$

- $\mathrm{O}$ Level of $\mathrm{Gl}$ in preliminary project phase

- Level of $\mathrm{Gl}$ in conceptual costing

$\rightarrow \bigcirc$ Community Projects
Adequate
Community restiveness pressure
Lacking

- $O$ Major projects

adequate

Lacking

Potically influenced

- $\mathrm{O}$ level of $\mathrm{Gl}$ in Planning Phase

adequate

Community considerations

lacking

(1) Potical Clout

6. 0 Nomencleture of project phases

ill-structured 


\section{Inductive Cluster Coding}

Two stages of cluster analysis were carried to bring the number of codes down, and to a more hierarchically structured network, more specific to the objective of the study: Clustering of interrelated micro-codes into more distinct subthemes; and clustering of subthemes into parent nodes. Some of the less distinct micro themes, which less repeatedly occurred were thus merged into each other, before clusters of parent themes were derived. Typically, the political related microthemes such as political designs, political procurement, and political influence, were clustered into a subtheme labelled political pressures. Similarly, all micro themes related to pressures from the local communities, such as community considerations and community youth restiveness, were clustered in to the subtheme labelled community pressures.

Major sets of technical and socially driven parent themes, emerged from the clusters of subthemes. These were derived from the respondents' descriptions of the mode of operation of the highway organisations, the nature of their relationship with the respective constituted institutional authorities; as well as the perception of the respondents' attitudes and description provided about other external socio-politically driven environments. The resulting hierarchical structure of the coding of the interview results is shown in Figure 4.

Following this thematic structure, an array of factors was identified from the deductive and inductive phases of the interview analysis, as actively contributing to cost overruns in the Niger Delta. Table 7 provides a summary of the factors and sub-factors extracted from the interview analysis, which constitute the latent geotechnical drivers and emergent social constructs representing the barriers to geotechnical input, escalating costs for in highway projects executed in the Niger Delta.

\section{Content Analysis of Induced Themes}

Further content analysis of the induced themes, based on the frequency of the coded references, provided the necessary quantitative platform to weigh the salience of the emergent themes, which

Figure 4. Hierarchical Structure of the Themes

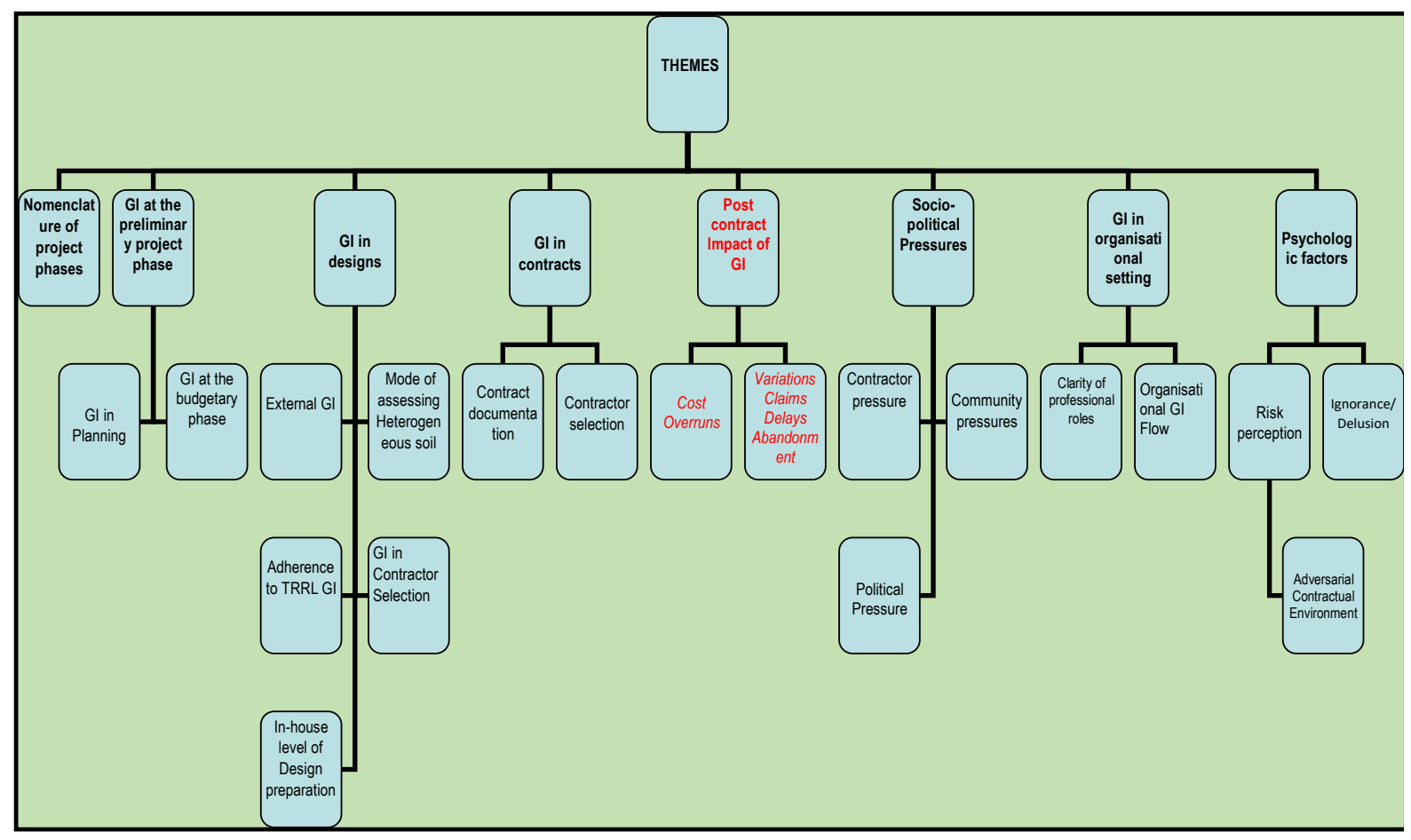


Table 7. Cost Overrun Drivers Inferred from the Deductive and Inductive Analysis

\begin{tabular}{|c|c|c|}
\hline Theme & Sub-Theme & Cost Overrun Drivers \\
\hline $\begin{array}{l}\text { Nomenclature of project } \\
\text { Phases }\end{array}$ & $\begin{array}{l}\text { Configuration } \\
\text { Pre-contract preparation }\end{array}$ & $\begin{array}{l}\text { III-Structured phase configuration } \\
\text { Poor Pre-contract preparation }\end{array}$ \\
\hline $\begin{array}{l}\text { Level of GI in preliminary } \\
\text { project phase }\end{array}$ & $\begin{array}{l}\text { Lack of GI in conceptual costing } \\
\text { lack of } \mathrm{GI} \text { in Planning Phase }\end{array}$ & $\begin{array}{l}\text { Community restiveness pressure } \\
\text { Lack of preliminary } \mathrm{GI} \\
\text { Community considerations } \\
\text { Lack of geo-route-selection }\end{array}$ \\
\hline Gl in designs & $\begin{array}{l}\text { Design preparation } \\
\text { Process } \\
\text { Mode of assessing } \\
\text { heterogeneous ground conditions } \\
\text { Non-Adherence to TRRL GI } \\
\text { Ext Consultant GI } \\
\text { DB contractors' GI }\end{array}$ & $\begin{array}{l}\text { Adhoc design preparation } \\
\text { Emergency designs } \\
\text { Reactive Post contract } \mathrm{GI} \\
\text { Uniform standard designs } \\
\text { Lack of Desk study } \\
\text { Lack of detailed GI } \\
\text { Based on preliminary reconnaissance } \\
\text { Non-verification of GI }\end{array}$ \\
\hline GI in contractual Phase & $\begin{array}{l}\text { Contract documentation } \\
\text { Contractor selection }\end{array}$ & $\begin{array}{l}\text { No DSC Clauses } \\
\text { Non-inclusion of GIR } \\
\text { Non-engineering Form of contract } \\
\text { Hand sketches designs } \\
\text { Survey Plan layout contract documentation } \\
\text { Verbal instructions } \\
\text { Emergency Procurement } \\
\text { No GI algorithm } \\
\text { Non -Technical bids }\end{array}$ \\
\hline $\begin{array}{l}\text { Organisational } \\
\text { dynamics }\end{array}$ & $\begin{array}{l}\text { Flow of GI } \\
\text { Clarity of professional roles } \\
\text { Geotechnical Presence } \\
\text { Contractual Porosity }\end{array}$ & $\begin{array}{l}\text { Poor organisational structure; } \\
\text { Mis-matched qualifications and job description } \\
\text { Lack of qualified technical manpower } \\
\text { Porosity of contractual system } \\
\text { Non-progressive GI } \\
\text { non-construction related professionals } \\
\text { No Role Specific Professional delineation; } \\
\text { Absence of in-house Geotechnical Personnel }\end{array}$ \\
\hline External Pressure & $\begin{array}{l}\text { Community pressure } \\
\text { Political pressure }\end{array}$ & $\begin{array}{l}\text { Community Considerations } \\
\text { Youth restiveness pressure } \\
\text { Emergency procurement } \\
\text { Contractors influence } \\
\text { Political interference } \\
\text { Unqualified contractors } \\
\text { Lack of due process in contracts } \\
\text { Unverified contractors' claims } \\
\text { Fear by professionals } \\
\text { Unplanned budgeting } \\
\text { Heightened security risk to contractors }\end{array}$ \\
\hline Psychologic barriers & $\begin{array}{l}\text { Adversarial contractual stance } \\
\text { De-motivation of professionals } \\
\text { Risk perception }\end{array}$ & $\begin{array}{l}\text { Counter geotechnical relations; } \\
\text { Oppressive Political influence } \\
\text { Poor risk perception } \\
\text { Unjustified expenditure for detailed GI; }\end{array}$ \\
\hline $\begin{array}{l}\text { Skills and Knowledge } \\
\text { Gaps }\end{array}$ & $\begin{array}{l}\text { Knowledge gaps in design } \\
\text { Knowledge gaps in procurement }\end{array}$ & $\begin{array}{l}\text { Lack of clear understanding of geo-risk } \\
\text { Ignorance of geotechnical best practices } \\
\text { Lack of awareness of current design practices } \\
\text { Non-discernible skills }\end{array}$ \\
\hline
\end{tabular}


Table 7 (Continued).

\begin{tabular}{|c|c|c|}
\hline GI Dichotomies & $\begin{array}{l}\text { Major Vs Community } \\
\text { Upland Vs Riverine }\end{array}$ & $\begin{array}{l}\text { Preferential management of geotechnical risk in relation to } \\
\text { project size; } \\
\text { Planned vs Adhoc procurement practices for major vs } \\
\text { community projects; } \\
\text { Politically motivated selective project management } \\
\text { practices; } \\
\text { Lower priority status in post contract management of riverine } \\
\text { projects relative to upland }\end{array}$ \\
\hline Unethical Practices & $\begin{array}{l}\text { Unethical professional practices of } \\
\text { consultants } \\
\text { Unethical professional practices of } \\
\text { contractors } \\
\text { Unethical in-house verification }\end{array}$ & $\begin{array}{l}\text { Deliberate under-design of projects } \\
\text { Replication of past GI reports } \\
\text { Replication of similar designs } \\
\text { Non-GI in DB designs } \\
\text { Contractors Influence of design preparation } \\
\text { Contractors Influence of contract award } \\
\text { Stifled verification of post-contract GI } \\
\text { In-house professionals serving in dual capacity as client and } \\
\text { contractors representative }\end{array}$ \\
\hline $\begin{array}{l}\text { Procurement } \\
\text { Irregularities }\end{array}$ & $\begin{array}{l}\text { Hushed and Unrealistic Bidding } \\
\text { Timelines } \\
\text { Subjective Procurement } \\
\text { Multiple Contract Re-Award }\end{array}$ & $\begin{array}{l}\text { Non-adherence to due contractual processes } \\
\text { Non-publicising of call for bid } \\
\text { Compressed timeline for tender submission } \\
\text { informal hierarchical chain of contract subletting } \\
\text { Multiple contract re-award }\end{array}$ \\
\hline
\end{tabular}

Deduced Themes (Latent Geotechnical Pathogens)

\section{Induced Themes (Contextual Drivers)}

were unanticipated in the drafting of the interview templates. The ranking of the barriers to geotechnical input are shown in Table 8, and used as a basis for assigning weights corresponding to the node sizes during further cognitive mapping.

As Table 8 shows, political pressure was referenced the highest number of times during the coding process, and as such has the highest weighting (Node sizing). The pattern of the responses, depicted that political influence mostly underlies the organisations' ability to adhere to geotechnical best practice. This was clearly the most repeatedly mentioned theme, in all the responses elicited from the highway officials which often created subjectivity in the procurement of highway projects, evident from a typical response: '...contracts are awarded based on recommendation from the *** or the *** without competitive bids being solicited from the public'. Community pressure in the form of youth restiveness was also described as a critical issue for projects executed in local communities, due to years of social deprivation and infrastructural neglect by successive government administration. This has led to a wave of insurgency characterised by violent demonstrations, hostage taking and bomb blasts by armed youths. Consequently, local community projects were normally executed on an emergency basis to calm youth restiveness without extensive pre-planning. Contractual porosity was weighted as the next most significant theme. Typically, the contractors interviewed explained that, most times consultants and in-house project monitoring teams did not bother to re-measure work during milestone payments.

All other ranking of themes was similarly weighted according to frequency of text referenced from the interview transcript. 
Table 8. Content Analysis of Emerging Themes

\begin{tabular}{|c|c|c|c|}
\hline Barrier & Sources & 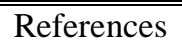 & Weighting \\
\hline Political pressure & 10 & 22 & 11 \\
\hline $\begin{array}{l}\text { Subjective } \\
\text { Procurement }\end{array}$ & 8 & 18 & 10 \\
\hline Community pressure & 10 & 15 & 9 \\
\hline Contractual porosity & 8 & 12 & 8 \\
\hline $\begin{array}{l}\text { Major Vs Community } \\
\text { Projects Dichotomy }\end{array}$ & 10 & 11 & 7 \\
\hline $\begin{array}{l}\text { Unethical } \\
\text { professional practices } \\
\text { of contractors }\end{array}$ & 8 & 9 & 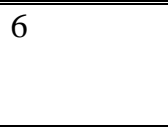 \\
\hline $\begin{array}{l}\text { De-motivation of } \\
\text { professionals }\end{array}$ & 7 & 8 & 5 \\
\hline $\begin{array}{ll}\text { Clarity } & \text { of } \\
\text { professional roles }\end{array}$ & 5 & 5 & 4 \\
\hline $\begin{array}{l}\text { Unethical } \\
\text { professional practices } \\
\text { of consultants }\end{array}$ & 4 & 5 & 4 \\
\hline $\begin{array}{l}\text { Adversarial } \\
\text { contractual stance }\end{array}$ & $\overline{5}$ & 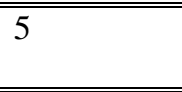 & 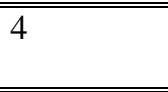 \\
\hline $\begin{array}{l}\begin{array}{l}\text { Knowledge } \\
\text { design }\end{array}\end{array}$ & 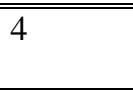 & $\overline{5}$ & 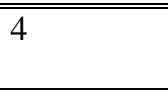 \\
\hline Flow of GI & 4 & 4 & 3 \\
\hline Risk perception & 3 & 4 & 3 \\
\hline $\begin{array}{l}\text { Upland Vs Riverine } \\
\text { Dichotomy }\end{array}$ & 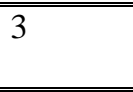 & 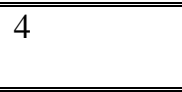 & 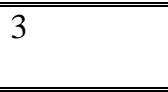 \\
\hline $\begin{array}{l}\text { Unethical verification } \\
\text { practices }\end{array}$ & 3 & 4 & 3 \\
\hline $\begin{array}{lr}\text { Hushed } & \text { and } \\
\text { Unrealistic } & \text { Bidding } \\
\text { Timelines } & \\
\end{array}$ & 3 & 3 & 2 \\
\hline $\begin{array}{l}\text { Geotechnical } \\
\text { Presence }\end{array}$ & 3 & 3 & 2 \\
\hline $\begin{array}{l}\text { Multiple Contract Re- } \\
\text { Award }\end{array}$ & 2 & 2 & $\overline{11}$ \\
\hline
\end{tabular}


Figure 5. Huff's Generic Families of Cognitive Maps (Source: McDonald et al., 2004)

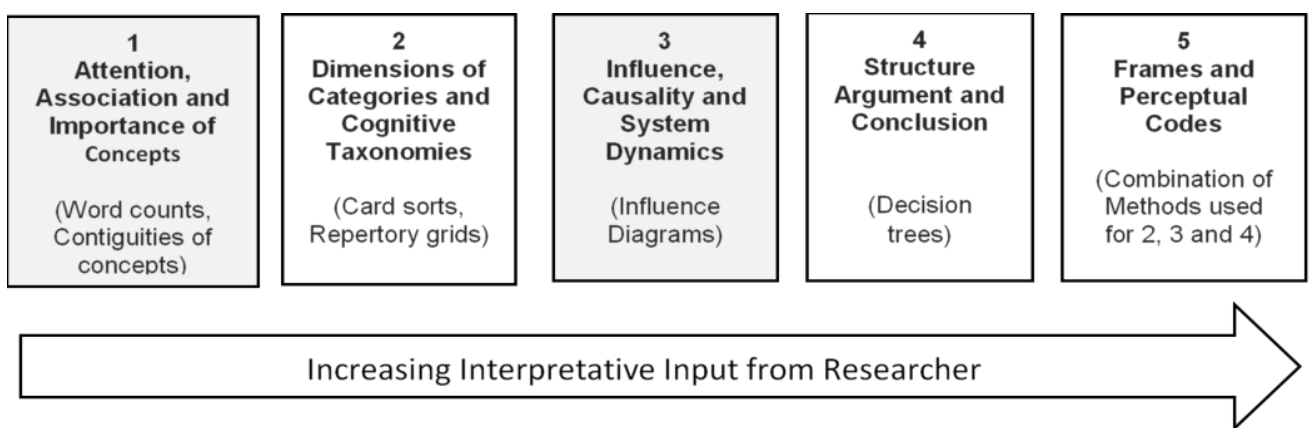

\section{Cognitive Mapping}

The final step in the qualitative analysis was the conceptual visual representation of the web of emergent cost overrun drivers, which ultimately interlinked with the linear construct of the core apriori geotechnical themes. Cognitive mapping is a tool useful for visual conceptualization, relevant to concisely represent linked qualitative data. It provides a framework for structuring ideas. The use of cognitive mapping is underpinned by the fundamental tenet of the hermeneutic circle which emphasises that qualitative research in its natural setting relies on understanding the whole and that the smaller bits of the enquiry are part of a whole and therefore do not operate in isolation (Bontekoe, 1996). Guba and Lincoln (1985) used the term 'Naturalistic inquiry' to describe qualitative research, asserting that qualitative research, unlike quantitative research have more complex interaction amongst the variables of the study. Cognitive mapping is thus useful to convey the outcome of theoretical abstraction from the data, by portraying the holistic interaction and causal links between multiple constructs simultaneously at play (Huberman and Miles, 1985).

Figure 5 is a generic categorisation of cognitive mapping approaches generally used in qualitative organisational research (McDonald et al., 2004). In line with the aim of developing an explanatory concept of cost overruns in highway projects, the study used a combination of type 1 and 3 of Huff's generic categories of maps in the cognitive mapping.

Cognitive Mapping was thus subsequently used to map out the interplay between the geotechnical pathogens deduced and the emergent themes (influences), which were represented as the barriers to geotechnical input. The cognitive mapping sought to highlight the system dynamics of causality, between the prevailing geotechnical practices and the induced contextual organisational, human and sociocultural factors, which have culminated to result in the unusually high levels of cost overruns experienced in highway delivery in the Niger Delta region.

By implication, the emergent themes induced from the analysis, plays out to ultimately distort the linearity implicit in the initial conceptual projection of the core geotechnical themes. Table 9 is an outline of the induced themes further configured as barriers complimentary to the latent geotechnical pathogens, identified from the practices of the highway agencies at the different progressive phases of project development, which was used as a basis for developing the cognitive map (Figure 6). The developed cognitive map is thus an intricately interwoven representation of causal links, between the core geotechnical themes (as initially preconceived as a mind map deduced from the literature), and the resultant cost overrun, with the emergent organisational and human related themes (as induced from the data) arrayed as influences at the respective phases, and whose node sizes were proportionally assigned to reflect their ranking. More frequently coded emergent themes, were inferred as having more significant impact on the levels of geotechnical input, and were thus represented in larger nodes. 
Table 9. Emergent Social Constructs as Complementary Cost Overrun Drivers

\begin{tabular}{|c|c|c|}
\hline Phases & Geotechnical Drivers & Emergent Social Constructs \\
\hline $\begin{array}{l}\text { Nomenclature of } \\
\text { pre-contract } \\
\text { phases }\end{array}$ & $\begin{array}{l}\text { Phase Configuration } \\
\text { Pre-contract preparation }\end{array}$ & $\begin{array}{l}\text { Flow of GI (FGI) } \\
\text { Clarity of professional roles (CPR) } \\
\text { De-motivation of professionals (DMP) }\end{array}$ \\
\hline $\begin{array}{l}\text { Preliminary } \\
\text { Phase }\end{array}$ & $\begin{array}{l}\text { Lack of GI in conceptual costing } \\
\text { Lack of GI in Planning Phase }\end{array}$ & $\begin{array}{l}\text { Risk perception (RP) } \\
\text { Lack of geotechnical presence (LGP) } \\
\text { Political pressure (PLP) } \\
\text { Community pressure (CMP) }\end{array}$ \\
\hline Design Phase & $\begin{array}{l}\text { Design preparation } \\
\text { Process } \\
\text { Mode of assessing } \\
\text { heterogeneous ground conditions } \\
\text { Non-Adherence to TRRL GI } \\
\text { Ext Consultant GI } \\
\text { DB contractors' GI } \\
\end{array}$ & $\begin{array}{l}\text { Unethical professional practices of } \\
\text { Consultants(UPCL) } \\
\text { Lack of Geotechnical Presence (LGP) } \\
\text { Risk perception (RP) } \\
\text { Knowledge gaps in design KGP) } \\
\text { Political pressure (PLP) } \\
\text { Unethical professional practices } \\
\text { of contractors (UPCRP }\end{array}$ \\
\hline $\begin{array}{l}\text { Contractual } \\
\text { Phase }\end{array}$ & $\begin{array}{l}\text { Contract documentation } \\
\text { Contractor selection }\end{array}$ & $\begin{array}{l}\text { Contractual Porosity (CP) } \\
\text { Adversarial contractual stance (ADC) } \\
\text { Knowledge gaps in procurement } \\
\text { Hushed Unrealistic Bidding Timeline } \\
\text { (HUBT) } \\
\text { Subjective Procurement(SP) } \\
\text { Political pressure (PLP) } \\
\text { Community pressure (PLP) } \\
\text { Risk perception(RP) }\end{array}$ \\
\hline $\begin{array}{l}\text { Post contract } \\
\text { Phase }\end{array}$ & $\begin{array}{l}\text { Delays and project abandonment due } \\
\text { to DSC }\end{array}$ & $\begin{array}{l}\text { Unethical professional practices of } \\
\text { contractors UPCR) } \\
\text { Unethical verification Process (UVP) } \\
\text { Major Vs Community Projects } \\
\text { dichotomy (MjCm) } \\
\text { Upland Vs Riverine Dichotomy (UpRv) } \\
\text { Multiple Contract Re-Award (MCR) } \\
\end{array}$ \\
\hline
\end{tabular}

\section{Discussion}

The cognitive map shows that, depending on the project class (major or community), dichotomous geotechnical practices (represented as diamond shaped nodes) are evident in the highway agencies. Community projects adopt a different nomenclature of implementation, mostly having an almost complete lack of geotechnical presence (GP) and input in the pre-construction, design and contractual phases of the project. The costing methods (at the conceptual and detailed estimate phase), mode of design preparation, as well as the adequacy of ground investigation carried out differed per project type, with crude tests and visual assessments used to assess ground conditions at community project sites. It was made clear that what constitutes designs for community projects are the schematic outlines of the scope of work as contained in the survey plans, which are subsequently used to prepare bill of quantities, supplemented by specification notes. The potential heterogeneity of ground conditions at project sites is thus not reflected in designs and estimates used 


\section{Figure 6: Cognitive Map of Geotechnical and Emergent Themes as Cost Overrun Drivers}

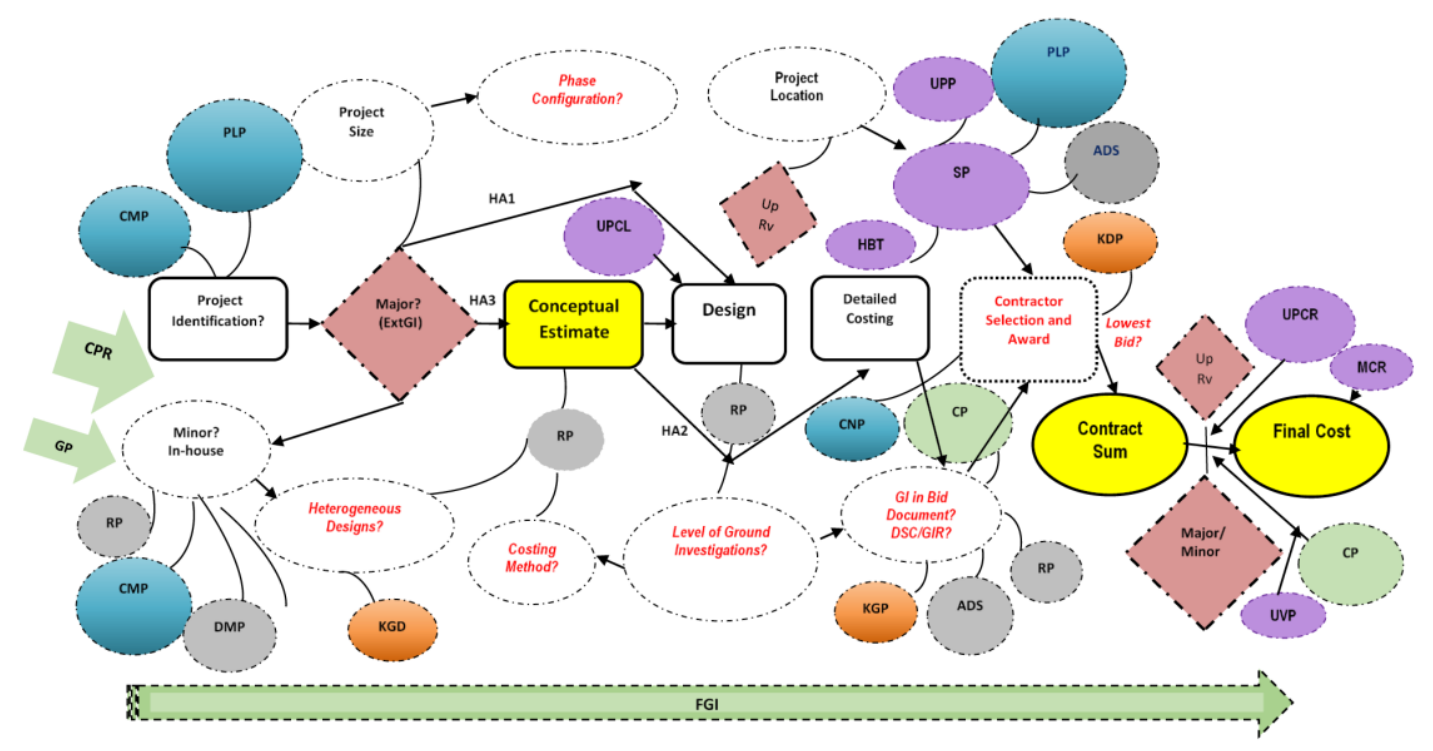

to award community road contracts. This is relative to major projects, whereby external consultants handle the full preliminary engineering and designs, with projects costed after the preparation of detailed designs.

At the contractual phase, however, both community and major projects evidence a noninclusion of GIRs and DSC clauses in bid documentation, with the highway agencies adopting the lowest bid criteria without an explicit geotechnical criterion in contractor selection. This raises doubts about the technical qualification of contractors executing highway projects in the region. The interview analysis results, from the contractors' perspective, further reveals that the non-inclusion of GIR/DSC clause, lack of clarity and in-consistency in designs and contract documentation are the principal issues which affected their ability to make informed pricing decisions when bidding for contracts, considering high level of geologic uncertainty associated with physical configuration of the terrain. The results show that this practice increases contractors' financial risk exposure, and has raised tensions and issues which have actively triggered contractual disputes leading to lengthy delays upon encountering differing physical conditions of site, other than anticipated by contractors. These dysfunctionalities as the cognitive map shows, are fostered by psychological traps such as low levels of Risk Perception (RP) latent in the highway organisations, with the procurement phase of projects characterised by an Adversarial Stance of the client against the contractors (ADS). Psychological traps can thus be inferred to have significant impact on the motivation of professionals in highway projects to adhere to geotechnical best practice.

The cognitive map however also highlights the dominant role of the organisational settings, people, and external factors, inherent in the institutional system, in determining the level geotechnical input (through the project phases). Several organisational pathogens (internal and external) were thus noted as latent backdrops to the geotechnical pathogens identified. As the cognitive map depicts, at project identification stage, external community and political pressures are active: conflicting Community Pressure (CMP) and dictatorial Political Pressure (PLP). The impact of 
political and community interference is particularly noted as being of a potent influence throughout the project cycle, with numerous multiplier impacts. Typically, the interview response show that this has led to heighted security risk to contractors, award of contracts to unqualified contractors, unplanned budgeting for highway projects, lack of due process in procurement as well as creating a Demotivating Professional working environment (DMP). Typically, the demotivation of professionals to apply geotechnical expertise in designs and costing was identified as a factor, which plays out to affect the quality of GI in projects. For instance, most respondents expressed an attitude of unquestioning acceptance of the power of political influence which weighs in oppressively on the performance of the professionals. A typical response to this effect was: 'As a professional working under the government, you have to be careful with the due diligence with which you carry out your responsibility... overzealousness could get you fired from the project team'.

Internal organisational pathogens such as the lack Clarity of Professional Roles (CPR), lack of inhouse Geotechnical Professionals (GP) and inefficient procurement practices leading to Contractual Porosity (CP) also prevail. The organisational loopholes were typified in the poor organisational structure of the highway agencies, the mis-matching of qualifications and job descriptions, the lack of qualified technical manpower, the understaffing of project supervisory team, the deployment of non-construction related professionals in projects. and the lack of professional delineation in the performance of tasks. It was noted that no clear-cut definition of professional roles existed within the highway organisations, consequently, most professionals serve in multiple capacities. Significant Knowledge Gaps in Design and Procurement of highway projects (KGD and KGP) were also evident amongst the highway professionals. Typically, the use of JCT, a non-engineering standard form of contracts, by the highway agencies was noted.

This is further compounded by unethical practices and other procurement irregularities external and internal to the organisational confines of the highway agencies such as Hushed and Unrealistic Bidding Timelines (HUBT); Subjective
Procurement (SP); Multiple Contract Re-Award (MCR), all of which constitute barriers to achieving adequate geotechnical input in highway projects. Typically, non-publicising of call for bids (at the contractual phase), deters technically efficient contractors from bidding for jobs; Compressed timeline for contractors to bid increases clients' financial risk exposure to differing site condition claims; Award of contracts to unqualified contractors, has led to an informal hierarchical chain of contract subletting with no binding geotechnical stake; multiple contract reaward has led to inconsistent and unaccountable geotechnical input in projects. Dichotomous project practices of the highway organisations in relation to project location with preference given to the management of the more visible upland projects relative to riverine projects located in the hinterlands, further aggravates the problem.

As the cognitive map depicts, the core geotechnical pathogens interplay within bulbs of organizational pathogens': 'Pressure Emitters'; 'Psychological Traps'; 'Skills Gaps'; 'Dichotomies' and 'Unethical Facilitators' of various scales, entrenched within the wider macro social value system and geo-political climate of highway development in the Niger Delta region. The array of issues uncovered thus represent pathogens latent in the highway organizations, which similar to Love et al.'s (2012) narrative, mostly lie dormant and have gone undetected, as they form part of the everyday practices of the highway organizations. These pathogens have actively combined to trigger a 'vicious cycle of delays and short funding', a theory previously conceptualized by Morris (1990), as a narrative specific to cost overruns in public projects in the developing world. Typically, the respondents explained the protocol followed by the agencies' in response to contractual claims and variation orders related to ground conditions, and the approximate timescale requisite to resolve such issues at the post contract phase. The respondents explained that the bureaucracy associated with gaining further budgetary approval often amount to lengthy delays since the additional costs were not part of the planned budget of the agency. For major projects, it was stated that: 'The contractor has to wait for the variation order to be approved. The approval process requires a lot of paper work and the application would have to move from one office 
determined by the pressure induced from political/community quarters. As Morris (1990:154) asserts, "Factors internal to the publicsector system and Government largely account for the delays and cost overrun in the developing world.

\section{Conclusion}

The use of cognitive mapping has provided an indepth exploration of the phenomena of cost overruns, relaying the holistic interaction and causal links between multiple variables, missing from the disjointed findings of existing theories on cost overruns in the developing world, which have shown a predisposition to using structured survey methods. The cognitive map has highlighted the trajectory showing how 'geotechnical pathogens' which often lay dormant within the linear process configuration of projects delivered by highway organizations, can be unintentionally triggered, inevitably culminating in cost overruns during the post-contract phase, as the project team deal with the cycle of delay and funding requirement. As the study uncovers, an array of geotechnical shortcomings in the practices of the highway agencies, have provided a fertile ground for inconsistencies and contractual disputes to prevail. The series of evidence has shown how the prevailing poor levels of geotechnical input constitute latent pathogens, which have triggered a chain reaction effect, right from the conceptual phase, consequently escalating cost and impacting on project delivery in the Niger Delta.

Furthermore, this study, framed within the context of highway project delivery in the developing world, has provided a measure of texture and feel of the insider view of Nigerian highway agencies, which have not been reflected in previous theoretical narratives. As the findings show, the issue of high cost overruns in Niger Delta's highway projects, cannot be divorced from the significant knowledge deficiencies of project actors, the numerous intra-organizational dysfunctionalities and the unstable/chaotic sociopolitical dynamics of the region. Therefore, despite the increased funding for the construction of new roads in the region, the multiplicity of internal and external organizational pathogens simultaneously 
at play, has further impacted on the agencies' inherently limited technical ability to properly plan for and manage funds allocated to highway projects in the Niger Delta.

Although the findings of this study are directly relevant to the geotechnical practice of the highway agencies operating in geologic setting of the Niger Delta region of Nigeria, such practice based geotechnical shortcomings may also be evident in other settings. As the literature reveals, there are still current arguments in the practice of highway organisations, surrounding:

- The use of historical data for conceptual cost estimating, with several scholars advocating that adequate expenditure should be devoted to carrying out more rigorous and comprehensive desk studies, to enable the use of more deterministic costing methods;

- The justifiable level of expenditure to be allocated to carrying out detailed ground exploration, and whether there is need to incorporate Ground Investigation Reports (GIR) and Differing Site Condition (DSC) clauses in engineering contracts, as a mechanism of geotechnical risk containment.

- The relevance of geotechnical presence, right from project inception, and not just for design purposes

This study thus depicts a case in hand showing how these widely-contested issues in geotechnical practice, still currently on going to various degrees in highway projects, can have significant financial impact on project completion cost. The study outcome thus shifts the emphasis in the cost overrun narrative to a more in-depth evaluation of geotechnical factors as major financial risk variables underlying all forms of transportation infrastructure projects. Effective evaluation of the geotechnical intricacies associated with highway projects, is therefore a crucial factor, on which the successful development of highway infrastructure needs to be predicated. However, to achieve this goal, the intrinsic socio-cultural issues contextual to highway agencies, which represent the human, organisational and institutional barriers to geotechnical input, would also need to be tackled conscientiously to create a conducive environment that prioritises geotechnical concerns.

\section{References}

Amadi, A (2016). Explaining Cost Overruns in Highway Projects: A Geo-Spatial Regression Modelling and Cognitive Mapping of Latent Pathogens and Contextual. An unpublished PhD Thesis submitted to the School of the Built Environment, University of Salford.UK.

Ajibade, A. and Odeyinka, H. (2006) Construction Delays and their Causative factors in Nigeria. Journal of Construction and Engineering Management. 132(7), 667- 677

Ashton, P. and Gidado, K. (2002). The Identification of uncertainty and risks associated with inadequate ground investigation procedures relative to project complexity. 18th annual conference of the Association of Researchers in Construction Management, UK

Association for the Advancement of Cost Engineering (1997) Recommended Practice No. 17R-97.

Ayodele, E.O. and Alabi, O. M. (2011). Abandonment of Construction Projects in Nigeria: Causes and Effects; Journal of Emerging Trends in Economics and Management Sciences (JETEMS), 2 (2), 142145.

BBC (2016). The Niger Delta Avengers: Nigeria's newest militants. [0nline]. Available at <http://www.bbc.co.uk/news/world-africa> accessed 22/04/2016.

Bontekoe, R. (1996). Dimensions of the Hermeneutic Circle. Atlantic Highlands, NJ: Humanities Press. Bryman, A. (1989). Research Methods and Organization Studies. Contemporary Social Research. Uwin Hyman Ltd

Cantarelli, C.C., Flyvbjerg, B., Molin, E.J.E and Van Wee, B. (2010). "Lock-in and Its Influence on the Project Performance of Large-Scale Transportation Infrastructure Projects. Investigating the Way in Which Lock-in Can Emerge and Affect Cost Overruns," Environment, Planning and Design, 37 (5): 792-807.

Central Bank of Nigeria. (2003). Highway Maintenance in Nigeria: Lessons from Other Countries. Research Department Occasional Paper Series, Central Bank of Nigeria, Abuja, Nigeria.

Chan, E. H. W. and Au, M. C. Y. (2007). Building contractors" behavioural pattern in pricing weather risks. International Journal of Project Management, 25(6), 615-626. 
Clayton, C.R.I. (2001). Managing geotechnical risk: Time for a Change. Proceedings ICE. Geotechnical Engineering. Paper 149. 3-11 Thomas Telford.

Creedy, D., Skitmore, M., Johnny, K and Wong, W. (2010). Evaluation of Risk Factors Leading to Cost Overrun in Delivery of Highway Construction Projects. Journal of Construction Engineering and Management. 528- 538.

Crowley, L and Hancher, D. (1995). Risk assessment of competitive procurement. Journal of Construction Engineering and Management, 121, 241-248.

Dlakwa M. M. and Culpin, M. F. (1990). Reasons for overrun in public sector construction projects in Nigeria. Lagos: Butterworth-Heinemann Ltd. Emujakporue, 2012

European Union. (2011). Infrastructure Development: Abandoned, Incomplete and Substandard Projects Sponsored by Federal, State, and Local Governments; Oil Companies and International Organizations since 2000. Report on Public Services, Good Governance and Development in Niger Delta Communities

Falade, D. (2016), NDDC project Audit, retrieved from http://tribuneonlineng.com/well-audit-nddc-projects

Fatokun, O.1. and Bolarinwa, A.I. (2009). Problem soils of Nigeria in road failure investigation. Technical Dept. Nigeria Building and Road Research Institute, (NBRRI), Report No. 13, 30.

Flyvbjerg, B., Skamris Holm, M.K. and Buhl, S.L. (2002). 'Underestimating cost in public works. Error or Lie?', Journal of the American Planning Association, 68(3), 279-295.

Gil, N and Lundriganm, C. (2012). The Leadership and governance of megaprojects, Centre for Infrastructure Development (CID), The University of Manchester. Report No.3/2012

Gransberg, D.D and Gad, G.M. (2014). Geotechnical Requirements in Design-Build Selection Process. Paper presented at the Transportation Research Board (TRB) National Academies Annual Meeting, Washington.

Guba and Lincoln (1985 Guba, E. G., and Lincoln, Y. S. (1994). Naturalistic Inquiry: London: Sage.

Huberman, A. M and Miles, M.B. (1985). Assessing Local Causality in qualitative research. In D.N. Berg and K.K. Smith Eds. Exploring Clinical Methods for Social Research. pp 351-381. New York: Sage.

Ihuah, P. W and Benebo, A. M. (2014). An assessment of the causes and effects of abandonment of Development projects on real property values in Nigeria. International Journal of Research in Applied, Natural and Social Sciences. 2(5), 25-36.

Institution of Civil Engineers. (1999). Inadequate site and ground investigations leading to construction delays and additional costs. Thomas Telford.
Isidiho, A.O and Sabran, M.S. (2015). Socio-political Impact of NDDC Infrastructural Projects on selected communities in Nigeria. Asian Journal of Humanities and Social Sciences. 3(2)

Johansen, A. (2015). Project Uncertainty Management: A New Approach- The 'Lost Opportunities' Practical uncertainty management seen from a project joint perspective. A Thesis submitted for the Award of a Doctor of Philosophy, Norwegian University of Science and Technology, Faculty of Engineering Science and Technology, Department of Production and Quality Engineering. Trondheim.

Joseph, U.N. (2012). Project delays in the Niger Delta region of Nigeria: Significant causes effects and solutions. An unpublished masters Dissertation submitted to the school of engineering and built environment. University of Witwatersrand, Johannesburg.

King, N. (2004). Interviews in Qualitative Research. The Modern Language Journal, 2011, Vol.95(4), pp.670-671

Love, P.E.D., Edwards, D.J, and Irani, Z. (2012) Moving Beyond Optimism Bias and Strategic Misrepresentation: An Explanation for Social Infrastructure Overruns. IEEE Transactions on Engineering Management 59(4):560-571

Lundrigan, C and Gil, N. (2013). Megaprojects: An Evolving Hybrid Meta-Organisation. Centre for Infrastructure Development, The University of Manchester. Working Paper 14/1

Mansfield, N.R., Ugwu, O.O. and Doranl, T. (1994). Causes of delay and cost overruns in Nigerian construction projects. International Journal of Project Management, 12(4), 254-260.

McDonald, S., Daniels, K and Harris, C. (2004). Cognitive Mapping in Organizational Research. In Essential Guide to Qualitative Methods in Organizational Research.

Molenaar, K.R., Diekmann, K.E. and Ashley, D.B. (2006). A Guide to Risk Assessment and Allocation. for Highway Construction Management, Report \# FHWA-PL-06-032, Federal Highway Administration, U.S.

Momoh, I. O, Akintorinwa, O. and Olonrunfemi, M. O. (2008). Geophysical investigation of Highway Failure- A case study from the basement complex terrain of Southwestern, Nigeria. Journal of Applied Sciences Research, 4(6): 637-648.

Morris, S. (1990). "Cost and Time Overruns in Public Sector Projects". Economic and Political Weekly, 47,154 to 168 . Indian Institute of Management, Ahmedabad

Morris, S. (2003). "Public Investment in India: Delays and Cost Overruns", India 
The Engineering Project Organization Journal (January 2018) Volume 8

Niger Delta Development Commission. (2013). About NDDC [Online]. Available at: http://www.nddc.gov.ng/ [Accessed 19 August 2014]

Ngerebara, O.D., Abam T. K. S and Nelson K. (2014). Geotechnical soil characterization of Akanfa-Gbaran Road, Bayelsa State, Nigeria. International Journal of Scientific and Research Publications, 4(4), 22-31.

Oguara, T. M. (2002). Sustainable Development of High Infrastructure in the Niger Delta Region. Proceedings of the Nigerian Society of Engineers (NSE) Conference. 4-10.

Okon, U.M. (2009). THE Niger Delta Development Commission's Approach to Infrastructure and SocioEconomic Development of the Niger Delta Region of Nigeria. A master's thesis report submitted to the Faculty of Engineering and the Built Environment, University of the Witwatersrand, Johannesburg.

Okpala, D.C. and Aniekwu, A.N. (1988). Cause of high cost of construction in Nigeria. Journal of Construction Engineering and Management, ASCE, 114 (2) 223-34.

Ossai, S.U. (2012). Nigeria: The Challenge of abandoned Projects in the Niger Delta. Journal of Public policy and Development, 2(3), 34-45.
Phillips, L.W. (1981). Assessing measurement error in Key Informant Report: A methodological note on organisational analysis in marketing. American Journal of Sociology, 79 (3). 686 -704.

PPAC. (2012). Report on NDDC projects. Presidential Projects Assessment Committee.

Reilly, J., Sangrey, D., Gabriel, M, Prill, W., and Shilbayay, S. (2004). Using Risk-based Evaluation The Success of CEVP. www.wsdot.wa.gov/projects/cevp/default.htm

Romero, V. S. and J. M. Stolz, (2009). Cost Estimating for Underground Transit: Too Dangerous to "Guesstimate". San Francisco, CA

Sunjka, B.P. and Jacob, U. (2013). Significant causes and effects of project delays in the Niger Delta region, Nigeria. SAIIE25 Proceedings, 9th -11 th of July, Stellenbosch, South Africa. 641-649.

Wong, J. (2012). What lies Beneath? An Over View of Claims relating to unforeseen Ground Conditions. Institute of Civil Engineers.

Yin, R. K. (2014). Case Study Research: Design and Methods (5th Ed.). Los Angeles: Sage.

The Engineering Project Organization Journal

(C)2017 Engineering Project Organization Society

www.epossociety.org 